\title{
TEMPLE UNIVERSITY RADIOCARBON DATES I
}

\section{KONETA ELDRIDGE}

Department of Geology, Temple University, Philadelphia, Pennsylvania 19122

\section{INTRODUCTION}

Temple's radiocarbon dating facility is housed in the Department of Geology on the Main Campus. The laboratory was established to support research in late Pleistocene and Holocene Geology, Archaeology, and Anthropology.

The method employed is liquid scintillation counting of synthesized benzene using the basic techniques described by Noakes, Kim, and Stipp (1965), Polach and Stipp (1967), and modifications as described by Stipp, Eldridge, and Cadwell (1976) converting sample $\rightarrow \mathrm{CO}_{2} \rightarrow \mathrm{C}_{2} \mathrm{H}_{2} \rightarrow \mathrm{C}_{6} \mathrm{H}_{6}$. Over-all yield is approximately 90 to $95 \%$. Shell samples are etched with dilute HCl; organic samples are pretreated with $3 \mathrm{~N} \mathrm{HCl}$ and, with the exception of total organic carbon dates, $2 \% \mathrm{NaOH}$.

Counting is done on an automatic Searle Mark III liquid scintillation spectrometer with a background of $7 \mathrm{cpm}$ utilizing a $20 \mathrm{cc}$ low ${ }^{40} \mathrm{~K}$ glass vial. The 4cc cocktail includes PPO and dimethyl-POPOP scintillators. Instrument stability is continuously monitored.

The dates reported here are calculated using a ${ }^{14} \mathrm{C}$ half-life of $5568 \mathrm{yr}$. $95 \%$ of NBS oxalic acid ${ }^{14} \mathrm{C}$ dating standard, converted to $\mathrm{CO}_{2}$ by a solution of potassium permanganate and sulfuric acid, is used for the modern reference. Errors are reported as one standard deviation which includes only the combined counting uncertainty of the background, modern, and sample. Ages of check samples determined in this laboratory indicate agreement with the results of other laboratories. Reproducibility of multiple runs is satisfactory.

\section{ACKNOWLEDGMENTS}

$\mathrm{R}$ Harper of Temple's Skin and Cancer Clinic generously provides use of his liquid scintillation counter. With his unselfish cooperation the laboratory is able to maintain efficient operation.

Special thanks to G Ulmer, Department of Geology, Temple Univ, for his support and encouragement. Student M Dobday supplied valuable assistance in various aspects of the laboratory's construction.

\section{SAMPLE DESCRIPTIONS}

\section{ARCHAEOLOGIC SAMPLES}

\section{A. United States}

TEM-129. Arthur Dean site, M52 SE-10-110

$1800 \pm 80$

Charcoal from Arthur Dean site, Sesachacha Pond W, Nantucket, Massachusetts $\left(41^{\circ} 17^{\prime} 35^{\prime \prime} \mathrm{N}, 69^{\circ} 59^{\prime} 62^{\prime \prime} \mathrm{W}\right)$. Sample excavated $65 \mathrm{~cm}$ beneath surface from midden located in glacial moraine. Result dates occupation of site by early peoples. Coll 1973 and subm 1979 by D G Crozier, Temple Univ, Philadelphia, Pennsylvania. 
TEM-111. Assunpink Creek, AS-1-44-3

Charcoal from Assunpink Creek, Hamilton Twp, New Jersey $\left(40^{\circ} 15^{\prime}\right.$ $\left.\mathrm{N}, 74^{\circ} 45^{\prime} \mathrm{W}\right)$. Sample in loose assoc with argillite assemblage from 35 to $45 \mathrm{~cm}$ beneath surface. Coll 1976 and subm 1978 by J W Gruber, Temple Univ. Comment: 2 nd date TEM-112: $2950 \pm 70$ from additional charcoal contemporaneous with TEM-111. Comment (JWG): 1st in series of samples to establish spatial chronology est 1150 to $6950 \mathrm{BP}$ of occupation by single component at this site.

\section{B. Pakistan}

TEM-118. Sanghao Caves 61 and 62

$11,760 \pm 260$

Charcoal from Sanghao Cave, Sanghao Valley, Peshawar Basin, Pakis$\tan \left(34^{\circ} 30^{\prime} \mathrm{N}, 72^{\circ} 30^{\prime} \mathrm{E}\right)$. Sample from hearth excavated $2 \mathrm{~m}$ beneath surface of cave floor. Result establishes regional sequence of archaeol cultures. Coll 1975 and subm 1978 by A J Ranere, Temple Univ. Comment (AJR): date expected to be much older from geol and cross-dating estimates. Sample assoc with stone tools which are probably contemporary with Upper Paleolithic industries to W.

\section{Guatemala}

TEM-113. El Mirador EM 78-1

$1450 \pm 120$

Charcoal from Aguada Limon reservoir, El Mirador, El Peten, Guatemala $\left(17^{\circ} 47^{\prime} \mathrm{N}, 89^{\circ} 55^{\prime} \mathrm{W}\right), 20$ to $50 \mathrm{~cm}$ beneath surface. Result dates abandonment of reservoir by early peoples during Classic or Post-Classic Maya phase. Coll by D K Moore; subm 1978 by B H Dahlin, Catholic Univ America, Washington, DC.

\section{Panama}

Temple Univ is currently involved with members of Am Mus Nat Hist and Smithsonian Tropical Research Inst in research directed towards assessing age and nature of early cultural patterns in New World humid tropics as well as age and nature of hunting-gathering patterns from which they developed. Attention has been focused on Pacific coastal plains of Panama where archaeol investigations conducted in 1940's and 1950 's revealed sequence of occupations spanning at least last $7000 \mathrm{yr}$ (Willey \& McGimsey, 1954; McGimsey, 1956; Willey, 1971). Re-excavation of Monagrillo and Aguadulce sites was undertaken during 1975 to coll archaeol and paleol samples for accurate dating and to reconstruct environmental and subsistence systems (Ranere, 1972; 1975; 1976; Ranere \& Hansell, 1978). Samples excavated in 1974 from the Ladrones site contained Monagrillo-like sherds, providing 3rd ceramic occupation for crossdating.

The following dates are latest radiocarbon results for Monagrillo, Aguadulce and Ladrones; previous dates are referenced where appropriate. Future work on these and additional sites will include coastal and intertidal sedimentol studies by Temple's Dept Geol. 
TEM-109. Monagrillo \#70

$5500 \pm 100$

Charcoal from coastal shell midden, $5 \mathrm{~km}$ NE of Chitre on coast of Parita Bay, Monagrillo, Herrera Province, Panama $\left(8^{\circ} 02^{\prime} \mathrm{N}, 80^{\circ} 28^{\prime} \mathrm{W}\right)$. Sample from Block 2, 100 to $110 \mathrm{~cm}$ beneath surface. Coll 1975 and subm 1978 by A J Ranere. Comment: previous dates on site are Y-585: $4090 \pm$ 70 (R, 1959, v 1, p 142-172); I-9384: $3325 \pm 85$ (Buckley, 1976, written commun); SI-2840: $3615 \pm 80$ and SI-2841: $5385 \pm 95$ (Stuckenrath, 1976, written commun).

\section{Aguadulce series}

Samples from rockshelter in coastal plains of central Panama, $18 \mathrm{~km}$ $\mathrm{N}$ on coast of Parita Bay, $8 \mathrm{~km} \mathrm{NE}$ of Santa Maria R, $13 \mathrm{~km} \mathrm{~W}$ of Aguadulce, Panama $\left(8^{\circ} 11^{\prime} 08^{\prime \prime} \mathrm{N}, 80^{\circ} 38^{\prime} 28^{\prime \prime} \mathrm{W}\right)$. Coll 1973 and subm 197879 by A J Ranere.

General Comment (AJR): stratigraphy was highly compressed yielding ca $5000 \mathrm{yr}$ of cultural deposits between 40 to $85 \mathrm{~cm}$ depth beneath surface.

TEM-107. Aguadulce \#30

$2570 \pm 100$

Ostrea corteziensis from Block 3, Layer $\mathrm{B}_{1}, 5$ to $10 \mathrm{~cm}$ beneath surface.

TEM-125. Aguadulce \#32

$\mathbf{2 5 4 0} \pm \mathbf{7 0}$

Ostrea corteziensis from Block 3, Layer $\mathrm{B}_{2}, 10$ to $15 \mathrm{~cm}$ beneath surface.

TEM-126. Aguadulce \#33

$2960 \pm 80$

Ostrea corteziensis from Block 3, Layer $\mathbf{B}_{3}, 15$ to $20 \mathrm{~cm}$ beneath surface. Comment (AJR): TEM-107, -125, and -126 are assoc with Monagrillo ceramics.

TEM-108. Aguadulce \#24

$3630 \pm 100$ face.

Ostrea corteziensis from Block 2, Layer $\mathrm{C}_{1}, 20$ to $25 \mathrm{~cm}$ beneath sur-

TEM-127. Aguadulce \#36

$2790 \pm 110$

Ostrea corteziensis from Block 3, Layer $\mathrm{C}_{3}, 25$ to $30 \mathrm{~cm}$ beneath surface. Comment: 2nd date TEM-128; $3700 \pm 100$ from Protothaca asperrima. Comment (AJR): TEM-127 expected to be older (assoc with preceramic culture); stratigraphically below TEM-108 and -126.

TEM-130. Aguadulce \#37

$4210 \pm 90$

Ostrea corteziensis from Block 3, Layer $\mathrm{C}_{4}, 30$ to $35 \mathrm{~cm}$ beneath surface. Comment: 2nd date TEM-131; $6180 \pm 120$ from Anadara tuberculosa.

TEM-106. Aguadulce \#40

$\mathbf{5 8 4 0} \pm \mathbf{1 0 0}$ bedrock.

Ostrea corteziensis from Block 3 , Layer $\mathrm{C}_{5}, 35 \mathrm{~cm}$ beneath surface to 
TEM-110. Aguadulce \#38 and \#41

$3540 \pm 120$

Charcoal from Block 3, Layer $\mathrm{C}_{4}$ and $\mathrm{D}$, \#38 from 30 to $35 \mathrm{~cm}$ beneath surface; \#41 from $35 \mathrm{~cm}$ beneath surface to bedrock. Comment (AJR): date expected to be older. Sample coll from both layers as small flecks; reworking by termites could have caused contamination. TEM-108, -127, $-128,-130,-131,-106$ and -110 are assoc with preceramic culture.

\section{Ladrones series}

Samples from rockshelter, Cueva de los Ladrones, Cocle, Panama $\left(8^{\circ}\right.$ $30^{\prime} 08^{\prime \prime} \mathrm{N}, 80^{\circ} 29^{\prime} 27^{\prime \prime} \mathrm{W}$ ). Coll 1974 by J Bird, Am Mus Nat Hist and R Cooke, Smithsonian Tropical Research Inst; subm 1978 by Bird and Cooke.

\section{TEM-120. Ladrones CL-46}

Ostrea from Area 2A, Layer 4, inside drip-line of rockshelter. Date expected to be late preceramic. Comment: 2nd date, TEM-121: $3860 \pm 90$ from Ostrea, Layer 5, contemporaneous with TEM-120.

TEM-123. Ladrones $\# 3_{\mathrm{c}}$

$6860 \pm 90$

Charcoal from 0 to $15 \mathrm{~cm}$ beneath surface, Area 2A, Layer 6. Sample assoc with earliest signs of occupation grading down to bedrock.

TEM-124. Ladrones $\# \mathbf{1}_{\mathrm{c}}$ $4520 \pm 100$

Charcoal lying on base rock, Area 1, Layer 2B. Correlation with early ceramic/late preceramic culture.

TEM-119. Ladrones CL-4

$4800 \pm 100$

Ostrea from 30 to $45 \mathrm{~cm}$ beneath surface, Area 1, Layer 3, assoc with Monagrillo-like sherds. Comment: sample stratigraphically related to TEM-124.

TEM-122. Ladrones $\# 2_{c}$

$3880 \pm 80$

Charcoal from Area 0, Layers 7 and 8. Date expected to be late preceramic.

\section{GEOLOGIC SAMPLES \\ A. United States}

TEM-114. Selbyville quad shell

Crassostrea fragments from Selbyville quad, Sussex Co, Delaware $\left(38^{\circ}\right.$ $29^{\prime} 05^{\prime \prime} \mathrm{N}, 75^{\circ} 08^{\prime} \mathrm{W}$ ), cored 2.4 to $2.8 \mathrm{~m}$ beneath surface of back barrier marsh environment. Result dates late Pleistocene coastal history in $\mathrm{E}$ Sussex Co. Coll and subm 1978 by J Demarest, Univ Delaware, Newark, Delaware. Comment: previous date on basal peat is I-7526: > 40,000 (Buckley, written commun). 


\section{TEM-115. Selbyville quad peat}

Peat sample from Selbyville quad, Sussex Co, Delaware $\left(38^{\circ} 29^{\prime} 05^{\prime \prime}\right.$ $\mathrm{N}, 75^{\circ} 08^{\prime} \mathrm{W}$ ), cored 8.2 to $8.6 \mathrm{~m}$ beneath surface. Result dates same geol event as TEM-114. Coll and subm 1978 by J Demarest. Comment: total organic carbon content dated.

TEM-116. Bethany Beach quad marsh mud

$4340 \pm 80$

Marsh mud from median strip on Rt 1, N of Indian R inlet, Bethany

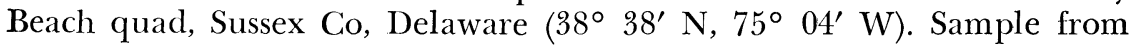
core ca $6 \mathrm{~m}$ beneath surface. Result dates presence of back barrier marsh subsequently buried under barrier island during transgression. Coll and subm 1978 by W Carey, Univ Delaware. Comment: total organic carbon content dated.

\section{TEM-117. Biddleford Pool spartina}

Spartina marsh grass from Biddleford Pool, Saco, Maine $\left(43^{\circ} 26^{\prime} \mathrm{N}\right.$, $70^{\circ} 21^{\prime} \mathrm{W}$ ), exposed in surf of transgressing sandy barrier. Date establishes rate of barrier transgression and relative sea level position. Coll and subm 1978 by J C Kraft, Univ Delaware. Comment: duplicate run of sample gave $1070 \pm 60 \mathrm{BP}$.

\section{REFERENCES}

Deevey, E S, Gralenski, L J, and Hoffren, Väinö, 1959, Yale natural radiocarbon measurements IV: Radiocarbon, v 1, p 144-172.

McGimsey, Charles, 1956, Cerro: A preceramic site in Panama: Am Antiquity,

Noakes, J E, Kim, S M, and Stipp, J J, 1965, Chemical and counting advances in liquid scintillation age dating: Internatl ${ }^{14} \mathrm{C}$ and ${ }^{3} \mathrm{H}$ dating conf, 6th, Proc, Pullman, Washington, June 7-11, 1965, p 68-92.

Polach, H A and Stipp, J J, 1967, Improved synthesis technique for methane and benzene radiocarbon dating: Internatl Jour Appl Radiation and Isotopes, v 18, p 359364.

Ranere, A J, 1972, Early human adaptations to New World tropical forests: the view from Panama: Ph.D. dissert, Dept Anthropol, Univ California, Davis.

1975, Report on the 1975 archaeological investigations at Monagrillo and the Aguadulce Shelter, Central Panama: Rept to the Patrimonio Hist del INAC, Panama. Unpub ms.

1976, The Preceramic of Panama: the view from the interior: 1st Puerto Rican symposium on archael Proc, San Juan, p 103-137.

Ranere, A J and Hansell, P, 1978, Early subsistence patterns along the Pacific Coast of Central Panama: Prehistoric coastal adaptations, New York, Academic Press, Inc.

Stipp, J J, Eldridge, K L, and Cadwell, R, 1976, University of Miami radiocarbon dates VI: Radiocarbon, v 18, p 210-220.

Wiley, Gordon, 1971, An introduction to American archaeology, v 2: South America, Englewood Cliffs, New Jersey, Prentice-Hall.

Willey, Gordon and McGimsey, Charles, 1954, The Monagrillo culture of Panama: Papers Peabody Mus Archaeol and Ethnol, v 49, no. 2, Cambridge, Massachusetts, Harvard Univ. 